\title{
PENGARUH PSY WAR TERHADAP KECEMASAN PERFORMA SHOOTING TWO POINT PADA PESERTA EKSTRA KURIKULER ATLET BOLABASKET
}

\author{
Fuad Azhar Nuh \\ IKIP Budi Utomo Malang \\ email : reffuad@gmail.com
}

\begin{abstract}
ABSTRAK
Psywar merupakan keadaan yang tercipta dari faktor lingkungan. Jika atlet mengalami hambatan pada faktor ini dikarenakan oleh psywar, Demikian pula yang terjadi dalam cabang olahraga bola basket.Penelitian ini menggunakan treatment by subject, dimana satu kelompok subjek diberi dua perlakuan, pertama dengan menggunakan psywar dan yang kedua tanpa psywar. Kelompok subjek penelitian ialah anggota tim bola basket SMKN 1GRATI yang berjumlah 8 orang.Untuk mengukur tingkat kecemasan, peneliti menggunakan metode angket.Angket diberikan kepada seluruh anggota tim yang bermain segera setelah pertandingan usai. Hal ini disebabkan karena pemberian angket saat pertandingan berjalan hingga paruh babak akan mengganggu konsentrasi pemain, dan hasil angket yang diberikan pemain pada paruh babak pertama belum tentu sama dengan hasil pada paruh babak kedua.Sedangkan untuk mengukur performa atlet, peneliti menggunakan lembar statistik pertandingan resmi yang diberikan oleh Perbasi Namun dalam penelitian ini, aspek yang digunakan two point shots percentage.Dari data yang diperoleh, ternyata peneliti memperoleh kesimpulan bahwa psywar yang diberikan oleh tim lawan kepada tim SMKN 1Grati sebagai subjek penelitian, ternyata tidak secara langsung mempengaruhi tingkat kecemasan dan performa atlet bola basket SMKN 1 Grati.
\end{abstract}

Kata Kunci: psy war, tingkat kecemasan, performa atlet

\section{ABSTRACT}

Psywar is a condition created by environmental factors. If the athlete experiences obstacles to this factor due to psywar, the same is true for basketball. This study uses treatment by subject, where one group of subjects was given two treatments, first using psywar and the second without psywar. The research group was 8 members of the 1GRATI Vocational High School basketball team. To measure the level of anxiety, researchers used the questionnaire method. The questionnaire was given to all team members who played immediately after the match was over. This is because giving a questionnaire when the match runs until the half of the round will disrupt the player's concentration, and the results of the questionnaire given by the players in the first half are not necessarily the same as the results in the second half. However, in this study, the aspects used were two point shots percentage. From the data obtained, it turned out that the researchers concluded that the psywar given by the opposing team to the 1Grati Vocational School team as the research subject did not directly affect the athlete's level of anxiety and performance basketball 1Grati SMKN.

Keywords:psy war, anxiety level, athletes performance

\section{PENDAHULUAN}

Psywar atau teror mental yang diterima seorang atlet di lapangan pada saat pertandingan dapat dikategorikan sebagai tekanan psikologis yang dapat memicu 
kecemasan pada atlet. Tekanan psikologis bagi atlet ini bisa bersifat besar maupun kecil tergantung dari jenis dan intensitas teror yang diterima atlet tersebut, serta kemampuan atlet untuk dapat beradaptasi dengan tekanan tersebut. Hal ini juga merupakan salah satu faktor yang dapat mempengaruhi kecemasan dan performa atlet secara eksternal, karena munculnya tekanan ini disebabkan oleh perlakuan yang dengan sengaja diberikan oleh pihak lawan. Misalnya: lawan dengan sengaja melakukan gerakan-gerakan yang bersifat provokatif pada anggota tim.

Hal ini akan membuat konsentrasi tim menjadi terpecah antara usaha untuk mempertahankan performa permainannya dan mencoba mengendalikan diri untuk tetap tenang. Keadaan tersebut memiliki dampak yang berbeda-beda bagi anggota, karena seorang atlet memiliki ciri-ciri kepribadian yang berbeda satu sama lain. Untuk menghadapi dan mengatasi tekananyang dilancarkan oleh lawan, maka seorang atlet harus mampu untuk mengendalikan dirinya dengan baik. Pengendalian diri bagi seorang atlet dalam pertandingan meliputi: konsentrasi untuk terus bermain sebagai tim, terus memotivasi diri untuk tampil baik, berpikiran positif, dan tidak cepat berpuas diri. (Marta Dinata, 2006)

Mengacu pada jurnal pengaruh metode pembelajaran part practice terhadap hasil belajar shooting bola basket ( Gurit Prastowo) keadaan tersebut, maka pengaruh yang dihasilkan pada setiap atlet akan berbeda-beda. Jika seorang atlet mampu beradaptasi dan mengendalikan diri dengan baik, maka ia akan menunjukkan performa tanpa merasakan kecemasan akibat perlakuan psywar yang dilancarkan lawan. Namun jika ia tidak menguasai keempat aspek pengendalian diri seperti diatas, maka atlet tersebut akan kehilangan konsentrasi yang berujung pada meningkatnya kecemasan dan menurunnya performa permainan. Karena olahraga bola basket adalah olahraga tim, maka pengaruh tersebut akan terlihat dari permainan yang mereka lakukan. Nantinya keadaan ini akan dapat terlihat dari statistika pertandingan (scoresheet, attempt dan scorer), dan game plan yang mereka susun untuk bertanding (dapat dijalankan dengan baik sesuai keinginan pelatih atau tidak).

\section{METODE}

Dalam penelitian ini menggunakan pendekatan eksperimen, dimana peneliti menyiapkan 12 pemain sebagai eksperimen yang akan diberi perlakuan dan satu 
kelompok kontrol yang tidak diberi perlakuan. Kedua kelompok tersebut merupakan satu tim bola basket yang beranggotakan beranggotakan dua belas orang, yaitu lima pemain inti dan tujuh pemain cadangan. Kelompok eksperimen adalah kelompok yang diberi perlakuan psywar (provokasi) selama pertandingan berlangsung, sedangkan kelompok kontrol adalah kelompok yang tidak diberi psywar dalam sebuah pertandingan. Karena tujuan penelitian ini ingin mengukur tingkat kecemasan dan performa tim sebagai sebuah kesatuan, maka tim yang sama melakukan dua kali pertandingan untuk pengukuran.

Peneliti mengambil sampel dari salah satu sekolah menengah kejuruan yang berada di kabupaten Pasuruan, yaitu SMKN 1 Grati yang memiliki sebuah tim bola basket yang cukup berprestasi. Dalam pemberian perlakuan peneliti membutuhkan waktu kurang lebih dua bulan. Dalam pemberian perlakuan psywar pada pertandingan, peneliti terjun langsung dalam eksperimen ini dengan menggunakan metode eksperimen treatment by subject dimana satu kelompok subjek diberi dua perlakuan. Tim/subjek penelitian melangsungkan dua kali pertandingan pada dua waktu yang berlainan. Pada pertandingan yang satu, tidak diberikan perlakuan (pertandingan biasa/sparring game). Sedangkan pada pertandingan kedua (dalam waktu yang jauh dari pertandingan pertama) perlakuan berupa psywar diberikan pada subjek penelitian.

Hasil untuk setiap tujuan penelitian: hasil perhitungan univariat, bivariat, multi variat

\section{HASIL PENELITIAN DAN PEMBAHASAN}

\section{1) Tingkat Kecemasan}

a. Tingkat Kecemasan Tanpa Perlakuan

Dalam mengukur tingkat kecemasan pada subjek penelitian, digunakan rumus pengkategorian sebagai berikut:

$$
\begin{aligned}
& \text { Tinggi }=\mathrm{X} \geq \mathrm{M}+\mathrm{Sd} \\
& \text { Sedang }=\mathrm{M}-\mathrm{Sd} \geq \mathrm{X} \leq \mathrm{M}+\mathrm{Sd} \\
& \text { Rendah }=\mathrm{X} \leq \mathrm{M}-\mathrm{Sd}
\end{aligned}
$$

Keterangan:

$$
\text { Mean } \quad=75.55
$$




$$
\begin{array}{ll}
\operatorname{Std} \operatorname{Dev}(\mathrm{Sd}) & =13.59 \\
\mathrm{M}+\mathrm{Sd} & =75.55+13.59=89.14 \\
\mathrm{M}-\mathrm{Sd} & =75.55-13.59=61.96
\end{array}
$$

Tabel 1 Tingkat Kecemasan Pada AtletTanpa perlakuan

\begin{tabular}{|l|l|l|l|}
\hline No. Punggung & \multicolumn{1}{|c|}{ X } & \multicolumn{1}{|c|}{ Kategori } & \multicolumn{1}{|c|}{ Skor } \\
\hline 8 & 69 & Sedang & 2 \\
\hline 9 & 76 & Sedang & 2 \\
\hline 10 & 77 & Sedang & 2 \\
\hline 11 & 56 & Rendah & 1 \\
\hline 12 & 69 & Sedang & 2 \\
\hline 13 & 98 & Tinggi & 3 \\
\hline 14 & 94 & Tinggi & 3 \\
\hline 15 & 78 & Sedang & 2 \\
\hline 16 & 63 & Sedang & 2 \\
\hline
\end{tabular}

Dari tabel diatas tampak bahwa tingkat kecemasan atlet dalam pertandingan tanpa perlakuan (psywar), tingkat kecemasan atlet dalam tim adalah 2 orang tinggi, 6 orang sedang, dan 1 orang rendah.

b. Tingkat Kecemasan Dengan Perlakuan

Pengkategorian Tingkat Kecemasan Dengan Perlakuan

Kategori:

$$
\begin{aligned}
& \text { Tinggi }=\mathrm{X} \geq \mathrm{M}+\mathrm{Sd} \\
& \text { Sedang }=\mathrm{M}-\mathrm{Sd} \geq \mathrm{X} \leq \mathrm{M}+\mathrm{Sd} \\
& \text { Rendah } \quad=\mathrm{X} \leq \mathrm{M}-\mathrm{Sd}
\end{aligned}
$$

Keterangan:

$$
\begin{aligned}
& \text { Mean } \quad=90 \\
& \operatorname{Std} \operatorname{Dev}(\mathrm{Sd})=22.05 \\
& \mathrm{M}+\mathrm{Sd}=90+22.05=112.05 \\
& \mathrm{M}-\mathrm{Sd}=90-22.05=67.95
\end{aligned}
$$


Tabel 2Tingkat Kecemasan Pada AtletDengan Perlakuan

\begin{tabular}{|c|r|c|c|}
\hline $\begin{array}{c}\text { No. } \\
\text { punggung }\end{array}$ & \multicolumn{1}{c|}{ X } & Kategori & Skor \\
\hline 8 & 109 & Sedang & 2 \\
\hline 9 & 114 & Tinggi & 3 \\
\hline 10 & 97 & Sedang & 2 \\
\hline 11 & 100 & Sedang & 2 \\
\hline 12 & 85 & Sedang & 2 \\
\hline 13 & 72 & Sedang & 2 \\
\hline 14 & 52 & Rendah & 1 \\
\hline 15 & 68 & Sedang & 2 \\
\hline 16 & 113 & Tinggi & 3 \\
\hline
\end{tabular}

Dari tabel diatas tampak bahwa tingkat kecemasan atlet dalam pertandingan tanpa perlakuan (psy war), tingkat kecemasan atlet dalam tim adalah 2 orang tinggi, 6 orang sedang, dan 1 orang rendah.

Tabel 3Perhitungan Tingkat Kecemasan 1 (Tanpa Perlakuan) dan

Kecemasan 2 (Dengan Perlakuan)

\begin{tabular}{|c|c|c|c|c|c|}
\hline $\begin{array}{c}\text { No. } \\
\text { punggung }\end{array}$ & $\begin{array}{c}\text { tingkat } \\
\text { kecemasan } \\
1\end{array}$ & $\begin{array}{c}\text { tingkat } \\
\text { kecemasan } \\
2\end{array}$ & $\begin{array}{c}\text { selisih } \\
(\mathrm{d})\end{array}$ & $\begin{array}{c}\text { d-d rata- } \\
\text { rata }\end{array}$ & $\begin{array}{c}\text { (d-d rata- } \\
\text { rata })^{2}\end{array}$ \\
\hline 8 & 2 & 3 & -1 & -0.67 & 0.44 \\
\hline 9 & 2 & 3 & -1 & -0.67 & 0.44 \\
\hline 10 & 2 & 3 & -1 & -0.67 & 0.44 \\
\hline 11 & 1 & 3 & -2 & -1.67 & 2.79 \\
\hline 12 & 2 & 2 & 0 & 0.33 & 0.1 \\
\hline 13 & 3 & 2 & 1 & 1.33 & 1.77 \\
\hline 14 & 3 & 1 & 2 & 2.33 & 5.43 \\
\hline 15 & 2 & 2 & 0 & 0.33 & 0.1 \\
\hline 16 & 2 & 3 & -1 & -0.67 & 0.44 \\
\hline
\end{tabular}




\begin{tabular}{|l|c|c|c|c|c|c|c|}
\hline Total & 19 & 22 & -3 & \multicolumn{2}{|c|}{-0.03} & \multicolumn{2}{|c|}{11.95} \\
\hline \multirow{5}{*}{} & & d rata-rata & -0.33 & & & & \\
\hline & & $\mathrm{Sd}^{2}$ & 1.49 & & & & \\
\hline & $\mathrm{Sd}$ & 1.22 & & & & \\
\hline & & $\mathrm{T}$ & -0.816 & & & & \\
\hline & & & & & & & \\
\hline
\end{tabular}

Berdasarkan perbandingan $\mathrm{t}$ hitung dengan $\mathrm{t}$ tabel, $\mathrm{t}$ hitung adalah 0.816.Tingkat signifikansi $(\alpha)$ adalah 5\%. Df atau derajat kebebasan adalah $n$ (jumlah data)-1 atau 9-1 = 8. Berdasarkan tabel statistik dengan melakukan uji dua pihak (two tailed test), maka diperoleh angka t tabel sebesar 2.306.Karena $\mathrm{t}$ hitung $-0.816<\mathrm{t}$ tabel 2.306, dan terletak pada daerah Ho diterima, maka bisa disimpulkan bahwa pemberian psy war ternyata tidak secara nyata mempengaruhi tingkat kecemasan atlet.

Berdasarkan nilai probabilitas, output Sig. 2-tailed dari Paired Samples TTest sebesar 0.438. Karena probabilitas > 0.05, maka Ho diterima atau dapat disimpulkan bahwa pemberian psy war ternyata tidak secara nyata mempengaruhi tingkat kecemasan atlet.

Tabel 4Perhitungan Two Point Shots PercentageTwo Point Shots 1 (Tanpa

Perlakuan) dan Two Point Shots 2 (Dengan Perlakuan)

\begin{tabular}{|c|c|c|c|c|c|}
\hline $\begin{array}{c}\text { no. } \\
\text { punggung }\end{array}$ & $\begin{array}{c}2 \text { point shots } \\
1\end{array}$ & $\begin{array}{c}2 \text { point } \\
\text { shots } 2\end{array}$ & $\begin{array}{c}\text { selisih } \\
(\mathrm{d})\end{array}$ & $\begin{array}{c}\mathrm{d}-\mathrm{d} \text { rata- } \\
\text { rata }\end{array}$ & $\begin{array}{c}\text { (d-d rata- } \\
\text { rata })^{2}\end{array}$ \\
\hline 8 & 0 & 0 & 0 & -0.098 & 0.009 \\
\hline 9 & 0 & 0 & 0 & -0.098 & 0.009 \\
\hline 10 & 0 & 0.33 & -0.33 & -0.428 & 0.183 \\
\hline 11 & 0 & 0 & 0 & -0.098 & 0.009 \\
\hline 12 & 0 & 0 & 0 & -0.098 & 0.009 \\
\hline 13 & 0.75 & 0.4 & 0.35 & 0.252 & 0.063 \\
\hline 14 & 0.4 & 0.25 & 0.15 & 0.052 & 0.002 \\
\hline 15 & 0.66 & 0 & 0.66 & 0.562 & 0.315 \\
\hline
\end{tabular}




\begin{tabular}{|c|c|c|c|c|c|}
\hline 16 & 0.71 & 0.66 & 0.05 & -0.048 & 0.002 \\
\hline Total & 2.52 & 1.64 & 0.88 & & 0.601 \\
\hline & & d rata-rata & 0.098 & & \\
\hline & & & & & \\
\hline & & $\mathrm{Sd}^{2}$ & 0.075 & & \\
\hline & & $\mathrm{Sd}$ & 0.274 & & \\
\hline & & $\mathrm{T}$ & 1.066 & & \\
\hline
\end{tabular}

Berdasarkan perbandingan $\mathrm{t}$ hitung dengan $\mathrm{t}$ table, $\mathrm{t}$ hitung adalah 1.066.Tingkat signifikansi $(\alpha)$ adalah 5\%. Df atau derajat kebebasan adalah $n$ (jumlah data) -1 atau 9-1 = 8. Berdasarkan tabel statistik dengan melakukan uji dua pihak (two tailed test), maka diperoleh angka t tabel sebesar 2.306. Karena $\mathrm{t}$ hitung $1.066<\mathrm{t}$ tabel 2.306, dan terletak pada daerah Ho diterima, maka bisa disimpulkan bahwa pemberian psy war ternyata tidak secara nyata mempengaruhi prosentase two point shots pada atlet.

Berdasarkan nilai probabilitas, output Sig. 2-tailed dari Paired Samples TTest sebesar 0.318. Karena probabilitas > 0.05, maka Ho diterima atau dapat disimpulkan bahwa pemberian psy war ternyata tidak secara nyata mempengaruhi prosentase two point shots pada atlet.

\section{HASIL DAN PEMBAHASAN}

Olahraga pada hakekatnya merupakan kegiatan fisik dan psikis yang dilandasi semangat perjuangan melawan diri sendiri, orang lain, maupun unsur alam yang jika dipertandingkan harus dilakukan secara ksatria sebagai upaya atau sarana untuk membentuk kepribadian dalam rangka meningkatkan kualitas hidup yang lebih luhur.Oleh karena itu, kegiatan olahraga perlu dikembangkan agar setiap orang dan khususnya para atlet dapat berpartisipasi dalam kegiatan olahraga tersebut, baik itu olahraga individu maupun olahraga beregu. (Marta Dinata, 2006)

Sesuai dengan tujuan diatas, maka olahraga tidak akan pernah dapat dipisahkan dari faktor-faktor yang mempengaruhinya baik yang bersifat internal maupun eksternal. Upaya-upaya terus dilakukan seorang atlet untuk mampu 
mencapai performa puncaknya. Hal ini membutuhkan jam terbang yang tinggi dan pengalaman serta wawasan bertanding yang baik.

PsyWar merupakan salah satu faktor eksternal yang mampu mempengaruhi ketegangan dan kecemasan seorang atlet dalam bertanding.Berdasarkan hasil penelitian yang dilakukan menggunakan metode eksperimen, diperoleh fakta bahwa keberadaan psywar tidak serta merta mempengaruhi tingkat kecemasan seorang atlet. Ketika seorang pemain memperoleh serangan berupa psywar, ia memang terkejut dan sedikit mengalami gangguan akan hal tersebut. Ternyata dalam sebuah pertandingan yang berlangsung 4x10 menit, seluruh pemain dalam tim mampu untuk melakukan adaptasi dan bermain seperti biasanya. Hal ini dapat dibuktikan dengan melihat scoresheet pertandingan. Pada quarter pertama, tekanan yang diberikan oleh tim pemberi perlakuan ternyata tidak membuat tim SMKN 1 GRATI menciut dan melemah.

Tekanan dan permainan cepat yang diperagakan oleh tim lawan memang sempat membuat mereka terkejut, namun keadaan ini justru membuat semangat dan motivasi tim terangkat sehingga mereka mampu mengimbangi permainan dan sempat unggul 13-10 pada quarter ini. Tim SMKN 1 GRATI mulai mengalami kesulitan akibat psywar dan tekanan yang dilakukan tim lawan sejak quarter dua dan seterusnya. Hal ini lebih dipengaruhi oleh pola komunikasi yang kurang akibat hilangnya konsentrasi karena tekanan-tekanan yang diberikan oleh tim lawan. Namun, mereka tetap termotivasi untuk berusaha menunjukkan semangat dan determinasi tinggi dalam permainan hingga pertandingan berakhir.Hal ini ditunjukkan dari perolehan angka dari quarter dua hingga empat. Mereka mampu menjaga selisih perolehan angka dari tim lawan tetap stabil dan tidak tertinggal jauh. Mengingat jam terbang dan usia pemain yang terpaut jauh antara tim SMKN 1 GRATI dengan CJBC (tim pemberi perlakuan), hasil 34-45 untuk kemenangan tim CJBC adalah wajar.

Namun, tim SMKN 1 GRATI telah menunjukkan bahwa tekanan yang mereka dapatkan dari psywar yang dilancarkan oleh tim lawan baik secara verbal maupun non-verbal, tidak secara langsung menjatuhkan dan mengacaukan permainan. Mereka mampu beradaptasi, dan menjadikan tekanan yang mereka alami sebagai motivasi untuk bermain lebih baik. 
Hal yang sangat kontras terjadi ketika tim SMKN 1 GRATI melakukan pertandingan biasa (tanpa perlakuan psywar) melawan tim sekelas, yaitu tim SMAN 1 GRATI Putra. Mereka bermain lepas dan sangat dominan dalam perolehan angka.Sejak quarter satu hingga empat, perolehan angka yang mereka dapatkan tidak mampu terkejar hingga memberikan keunggulan akhir 4417.Namun, sekali lagi perlu ditekankan bahwa perolehan angka adalah hasil.Permainan, pola komunikasi, motivasi, dan kedewasaan dalam bertanding lebih dilihat dan diutamakan dalam pertandingan ini. Tanpa adanya psywar dari tim lawan, mereka mampu menunjukkan itu semua di lapangan dan bermain sangat baik.

Seperti telah disepakati bersama bahwa untuk meningkatkan prestasi seorang atlet bukan hanya dilihat dari segi kemampuan fisiknya saja, namun juga sangat dipengaruhi oleh faktor psikis dari seorang atlet itu sendiri.Demikian pula yang terjadi dalam cabang olahraga bola basket.Bola basket, selain menuntut ketrampilan dan kemampuan fisik yang prima, dilain sisi juga membutuhkan kestabilan dan kematangan psikologis. Hal ini dapat secara jelas dilihat pada seorang atlet yang akan melakukan shooting ke keranjang yang apabila ia mengalami gangguan terhadap psikisnya, maka muncul kemungkinan tembakannya tidak akan berhasil. Namun, jika atlet tersebut memiliki kestabilan dan kekuatan psikis yang baik, maka ia akan dengan tenang melepaskan tembakan dan memiliki kemungkinan berhasil jauh lebih baik.

Jika ada atlet yang mengalami ketegangan atau kecemasan paling banyak, maka atlet tersebut ialah seorang atlet pemula.Hal ini disebabkan oleh kurangnya pengalaman bertanding, serta belum terlalu berkembangnya kemampuan teknik yang dimilikinya dalam menghadapi pertandingan. Dengan kata lain, ketegangan maupun kecemasan dari seorang atlet dipengaruhi oleh dua faktor yaitu faktor internal dan faktor eksternal.

Sedangkan pada variabel performa atlet, hasil data penelitian yang menggunakan analisa dua sampel berpasangan dari data yang diperoleh pada masing-masing pertandingan menunjukkan bahwa empat faktor yang menunjukkan performa atlet dalam sebuah pertandingan juga tidak menampakkan perbedaan yang signifikan.Hasil akhir yang ditunjukkan pada scoresheet masing- 
masing pertandingan memang menampakkan perbedaan yang jelas dari segi jumlah poin yang diperoleh dan hasil akhir pertandingan yang berbeda.

Namun, untuk prosentase memasukkan bola tiap-tiap pemain dalam tim dalam dua pertandingan yang berbeda, baik itu free throwdan two point setelah dianalisa menggunakan paired samples t-test juga tidak menunjukkan perbedaan yang signifikan antara keadaan bertanding biasa dan bertanding dengan unsur psy war di dalamnya. Hal ini berarti, pemain atau atlet dalam tim tersebut mampu melakukan adaptasi dan mengurangi ketegangan dan kecemasan saat situasi pertandingan berubah.Karena jika tekanan diberikan kepada atlet dan menimbulkan ketegangan dan kecemasan dalam dirinya, namun atlet tersebut tidak secara langsung terpengaruh kemudian dapat bermain dengan semangat dan ketenangan, maka atlet tersebut telah melakukan adaptasi terhadap tekanan dan pengaruh eksternal (psy war) yang terjadi di lapangan.(Marta Dinata, 2006)

Dari beberapa dampak negatif yang diakibatkan oleh pengaruh ketegangan atau kecemasan, sebenarnya ada beberapa dampak positif yang dihasilkan.Dalamkeadaan tertentu ketegangan atau kecemasan seperti psywardapat memberi keuntungan bahkan diperlukan untuk mencapai prestasi yang lebih baik. Hal ini disebabkan karena dengan ketegangan yang ditimbulkan, mental seorang atlet disiapkan untuk mampu menghadapi situasi yang tidak pernah sama dalamsebuahpertandingan. Semakin sering ia memperoleh ketegangan atau kecemasan dalam pertandingan, maka ia akan semakin matang untuk melatih mentalnya dalam menghadapi pertandingan-pertandingan yang akan dijalani. Kepercayaan diri dari seorang atlet sangat dipengaruhi oleh kondisi dan kemampuan atlet itu sendiri. Oleh karena itu, seorang atlet harus bisa menilai kekuatan-kekuatan dan kelemahan-kelemahan lawannya, sehingga ia sendiri bisa menilai dirinya sendiri untuk dapat menambah rasa percaya diri yang dimilikinya, tanpa terlalu banyak dipengaruhi oleh faktor-faktor penghambat dalam setiap pertandingan.

Isi simpulan merupakan pernyataan singkat tentang hasil analisis deskripsi dan pembahasan tentang hasil pengetesan. Kesimpulan berisi jawaban atas pertanyaan yang diajukan sesuai permalahanan. Keseluruhan jawaban hanya 
terfokus pada ruang lingkup pertanyaan dan jumlah jawaban disesuaikan dengan jumlah rumusan masalah yang diajukan.

\section{SIMPULAN}

Performa atlet diperoleh hasil dengan rincian sebagai berikut:Two Points Shots: Ho diterima, maka bisa disimpulkan bahwa pemberian psywar ternyata tidak secara nyata mempengaruhi prosentase two point shots pada atlet.

Dengan demikian maka dapat disimpulkan bahwa psy war yang diberikan oleh lawan dan dialami oleh tim SMKN 1 GRATI, ternyata tidak secara langsung mempengaruhi tingkat kecemasan dan performa atlet bola basket SMKN 1Grati. Berdasarkan observasi dan analisa scoresheet, hal ini disebabkan oleh munculnya motivasi yang tinggi serta kemampuan adaptasi terhadap tekanan yang dialami oleh pemain dalam menghadapi sebuah pertandingan, sehingga mereka mampu untuk mengimbangi permainan dan bermain tetap dengan pola yang seperti biasa mereka lakukan.

\section{DAFTAR PUSTAKA}

FIBA. (2010). Official Basketball Rules 2010. Referees'Manual: Two-person officiating, (October), 1-33.

Marta Dinata. (2006). Bola Baskest.

Monty P. Satiadharma. (2002). Psikologi Latihan.

Pengaruh metode pembelajaran part practice terhadap hasil belajar ( studi pada siswa kelas xi-ips sma negeri 1 cerme ) gurit prastowo abdul rachman syam t abstrak

Albin, Rochelle. Emosi; “Bagaimana Mengenal, Menerima, dan

Mengarahkannya”. Yogyakarta: Kanisius, (1986).

Atkinson, Rita., Atkinson, Richard., Smith, E.E., Bem, D.J. "Pengantar Psikologi”, Edisi Kesebelas, Jilid Satu. Batam Centre: Interaksara.

Auwee, Y.V., Bakker, F., Biddle, S., Durand, M., dan Seiler, R. "Psychology For Physical Educators”. Champaign, Illinours: Human Kinetics Publishers, Inc, (1999). 
Calhoun, D.W. "Sport, Culture, an Personality”. Champaign, Illinours: Human Kinetics Publishers, Inc, (1981).

Dinata, Marta. “Bola Basket”. Ciputat: Cerdas Jaya, (2006).

FIBA, PERBASI. "Bola Basket Untuk Semua”. Jakarta: Bidang III Perbasi, (2006).

Irsyada, "Machfud. Bola Basket”.Depdiknas, 2000.

Maramis, W.F. “Catatan Ilmu Kedokteran Jiwa”. Surabaya: Airlangga University Press, (1995).

Nazir, Moh. “Metode Penelitian”. Jakarta: Ghalia Indonesia, (1988).

Satiadharma, Monty. "Psikologi Latihan". (2002).

Sudjana.Metoda Statistika-edisi ke 6. Bandung: Tarsito, (1996).

Sugiyanto. "Rancangan Eksperimen (PSO 602)”. Universitas Gadjah Mada, (1995).

Sugiyono. “Statistika Untuk Penelitian”. Bandung: Alfabeta, (2003).

Sujudi, Imam. "Permainan dan Organisasi Pertandingan". Jakarta: Karunia Universitas Terbuka, (1986). 